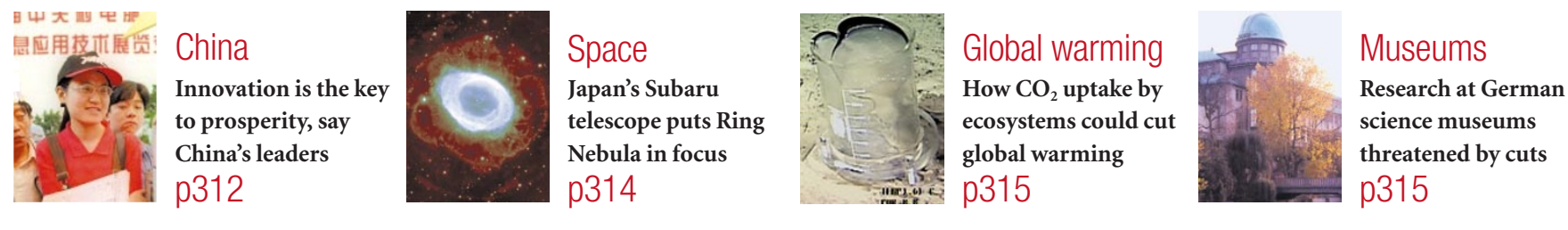

\title{
Gene estimate rises as US and UK discuss freedom of access
}

London

One of the leading private-sector participants in US genome sequencing efforts says he has firm evidence that there may be more than 140,000 genes in the human genome - a significant increase over conventional estimates closer to 100,000.

Randall Scott, president and chief scientific officer of the biotechnology company Incyte Pharmaceuticals, suggested this new figure during a presentation on Monday (20 September) to the annual sequencing conference organized in Miami, Florida, by the Institute for Genomic Research (TIGR).

His announcement coincides with the news that the chief scientific advisers to the US and British governments, Neal Lane and Robert May respectively, have been discussing a joint declaration underlining the commitment of their governments to public access to raw sequence data.

Scott's new estimate of the number of human genes will come as little surprise to most researchers. Already one result of sequencing work on other organisms, for example the fruitfly Drosophila, has been to increase the estimate of the number of genes these organisms contain, usually by a factor of about 20 per cent.

Nevertheless, the higher number will be of considerable interest to geneticists, particularly as it follows other suggestions that the total number of nucleotide bases in the genome is considerably more than the figure of three billion usually quoted in debates on sequencing projects.

Scott's new estimate of the total number of human genes is based on an analysis of the prevalence in genes of CpG islands - short stretches of DNA that can be methylated and as such provide a mechanism for controlling gene expression (for full details see http://www.incyte.com).

Incyte has already produced a large bank of sequence data that is made available for searching by other companies and research institutions on a contract basis. Incyte researchers have sequenced just under half of the CpG islands and compared them to the finished sequences of genes now available.

"This has allowed us to estimate that, over-

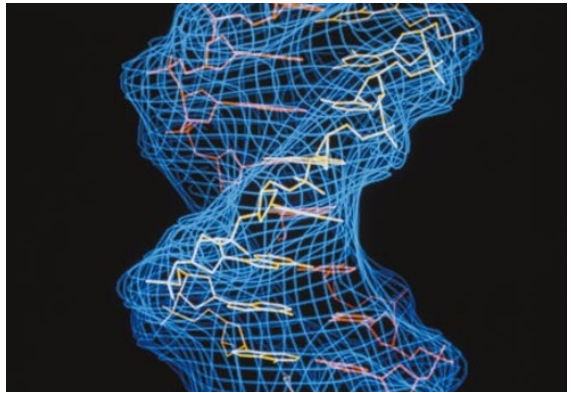

How many genes in the human genome? 142,634 according to Incyte Pharmaceuticals.

all, 53 per cent of genes have CpG islands associated with them," says Scott. A further estimation that there are just over 75,000 CpG islands in total in the genome has led Scott and his team to predict a total of 142,634 genes.

"Previous recent estimates appear to have been substantially lower than this because they have overestimated the frequency of CpG islands in genes," he says. "One of the implications is that the genome is even more complex than we originally thought."

Incyte's calculations are likely to increase interest in the question of patenting of sequencing data, which produced headlines in Britain this week when The Guardian revealed the discussions between Washington and London on a possible joint declaration on access to sequence data. The report was later confirmed by the Department of Trade and Industry.

Officials on both sides of the Atlantic were quick to point out, however, that such a declaration would be aimed primarily at ensuring rapid access to raw sequence data, rather than preventing the patenting of genetic data as such (including the right to patent a specific gene when its sequence data is linked to a specified application).

The move has been welcomed by Britain's Wellcome Trust, which is sponsoring one third of the total human genome sequencing effort. The trust has been insistent - together with its US partners - that one condition of its support is that all such data is made publicly available within 24 hours.

John Sulston, director of the Sanger Centre near Cambridge, which is jointly funded by Wellcome and the Medical Research Council, says: "This data must be shared and controlled by all, and I strongly endorse the idea of giving the human genome an international ownership' flavour in this way”. David Dickson

\section{Putting a price on research reading}

Paris

Journals produced by not-for-profit organizations are generally better value for money than those of commercial publishers. This is the conclusion of a study by the University of Wisconsin library of the costs and impacts of journals in physics, neuroscience and economics.

The data were collected last year to commemorate a famous study carried out a decade earlier by Henry Barschall for the American Institute of Physics. The original study came to prominence when the Swissbased publisher Gordon \& Breach, whose journals fared badly in the study, sued the institute (whose journals came off well).

Earlier this year, the US Court of Appeals for the Second Circuit threw out Gordon \&
Breach's case, concluding that the study was reliable, and that publication and promotional use of a survey of journal prices did not constitute false or misleading advertising(see Nature 397, 465; 1999). Barschall died before the verdict was known.

The new study confirms that the trends highlighted by Barschall still exist, for example, the wide variation in the cost of journals per 1,000 characters. Physics journals varied by a factor of 36 , for example, from 0.76 cents to 27.33 cents. Even greater variation was found when journals were assessed on their 'impact factor', a value ranging from 0.2 to 182 cents.

Of the three fields included in the study, the average cost per 1,000 characters was lowest in physics at $\mathbf{9 . 8 4}$ 
cents; the cost for economics journals was $\mathbf{1 0 . 6 0}$ and that for neuroscience journals 13.83.

But in terms of cost-effectiveness, as measured by the ratio of cost to impact, neuroscience, at 7.7, emerged better than physics journals (11.5) and much better than economics publications (29.8); a lower ratio denotes better costeffectiveness.

Ten years after the Barschall study, not-for-profit publishers again emerged in general as a better bargain in terms of cost/impact than commercial publishers. Commercial journals scored worse than not-for-profit journals in all three disciplines: 14.61 versus 8.23 in physics, 42.62 versus 11.55 in economics and 8.69 versus 0.64 in neuroscience.

Nature was not included in the study. But data also gathered by Wisconsin library on the use of thousands of its journals show Nature to be one of the most cost-effective journals in terms of 'cost per use' (http://www.wisc.edu/ wendt/journals/costben/stee8.pdf).

Nature's average cost-per-use was 62 cents last year, and as low as 18 cents at one library. In contrast, over 600 journals had cost-per-uses of more than $\$ 45$, with some as high as $\$ 700$. Declan Butler

\section{Bombing of embassy bolsters support for science in China...}

Beijing

The efforts of China's research community to argue for policies that favour technological innovation have received a boost from an unexpected quarter - NATO's bombing of the Chinese embassy in Belgrade, Yugoslavia, last May.

The bombing appears to have led to a greater recognition of the importance of science and technology by the Chinese people, including top government officials. The development of cutting-edge technologies is regarded as crucial to national security. Privately, scientists are saying that the bombing has stimulated the government into increasing its attention to science and technology.

Last week, 23 scientists were awarded gold medals — some posthumously — for their contributions to the development of China's first nuclear weapons, missiles and first satellite. The medals were presented by president Jiang Zemin at a ceremony in the Great Hall of the People in Beijing.

The ceremony was presided over by $\mathrm{Li}$ Peng, chairman of the National People's
Congress. Jiang and prime minister Zhu Rongji addressed the meeting, speaking highly of the achievements of the scientists. All Politburo members and top government officials were present.

"Without national defence, there will be no nation; without a national defence industry, there will be no national defence," said Zhu recently. A statement issued by the government says: "Without grasping state-ofthe-art technologies, we will be bullied."

In the weeks after the bombing, discussions in the science community emphasized the achievements of Chinese scientists in developing the nation's first atomic and hydrogen bombs, and missiles, in the 1960s. Participants stressed the need for China to develop its own high technologies so that the United States could no longer bully it.

The bombing appears to have increased the respect given to scientists. Leading scientists from military research organizations have been invited to talk on television about the technologies used by NATO in its bombing of the embassy.

Tian Xuewen

\section{... as government sets sights on an 'innovation economy'}

\section{Beijing}

China has confirmed its commitment to encouraging closer links between research institutions and industry, and has instructed all government departments to draw up plans for helping to create an innovationbased economy.

Political bodies have called for greater rewards for scientists and engineers responsible for successful innovations. They will now be allowed to hold shares in companies that exploit their inventions commercially.

The endorsement of the importance of high technology to economic prosperity came during a four-day meeting at the end of last month in Beijing, chaired by prime minister Zhu Rongji and attended by president Jiang Zemin and members of the Politburo, the top authority in China's power hierarchy.

The conference was held to increase awareness among party and government officials of the need to boost technological innovation. A statement issued by the party central committee and the state council before the meeting lists various steps to achieve this. These include accelerating the technological upgrading of traditional industries and increasing the knowledge content of the service sector.

Following the meeting, all major govern-

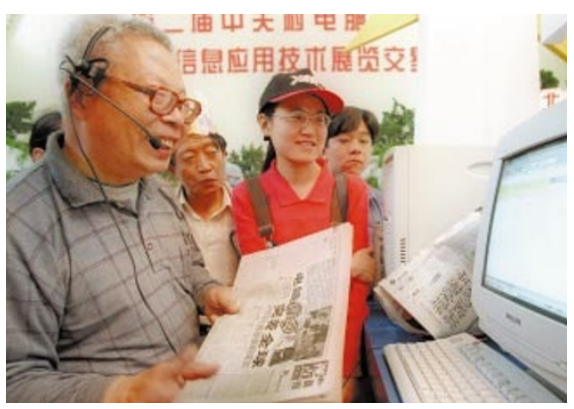

Great leap forward: the Chinese public is being encouraged to embrace high technology.

ment agencies are discussing how to put these principles into practice. "We will come out with an action plan very soon," says a spokesman for the science ministry.

Science minister Zhu Lilan said the government wanted industries to become the main force in promoting innovation, and that mechanisms should be set up for using venture capital to help achieve this.

$\mathrm{Xu}$ Guanhua, vice-minister of the science ministry, said in a television interview that there was inadequate interaction between research institutions and industry in China. As a result, scientific findings were often left unexploited for years. This situation will improve in the future, said $\mathrm{Xu}$, as technologi- cal brokers will be given a greater role in bring ing research institutions and industry closer.

$\mathrm{Xu}$, an expert on remote sensing and former vice-president of the Chinese Academy of Sciences, also expressed concern about the low level of state support for research and development. In 1997, China's spending on research and development was only 0.64 per cent of its gross domestic product. In 1998, the total spending in China was less than the increase in spending alone in the United States over the previous year.

The Chinese Academy of Sciences, China's major research organization, was also due to produce an action plan, to be decided by a top-level meeting on 9 September. But no details have been released yet.

The academy was traditionally focused on basic science, but has been dedicating increasing efforts to applied science and industrial research in recent years. It was selected by the government a year ago to be a target for reform under the National Knowledge Innovation Campaign. More radical reforms of the academy are expected to follow from the conference.

Science parks and high-technology industrial development zones will attract more attention as a result of the conference, according to a paper from the science ministry. T. $\mathbf{x}$. 